\title{
Innføring av PET i Norge - ikke for sakte eller for sent?
}

\author{
Takket være en godt planlagt og koordinert prosess er vi i Norge på god vei mot en kontrollert innføring \\ av positronemisjonstomografi (PET). Kritikken av sendrektighet og lavt ambisjonsnivå er feilslått.
}

Positronemisjonstomografi (PET) er en bildediagnostisk teknologi som særlig benyttes i utredning eller oppfølging av kreftpasienter, men også ved behandling av hjertesykdom og nevrologiske tilstander. Med jevne mellomrom er det blitt hevdet at norske helsemyndigheter har undervurdert behovet for undersøkelsen og lagt seg på et for lavt ambisjonsnivå for utbygging av PET-tilbudet (1).

Som deltakere i denne prosessen vil vi hevde at helsemyndighetene gjennom de siste ti årene har vært tett på problemstillingen om PET-teknologien. Beslutninger om PET er tatt både på vurdering av dokumentasjon fra forskning og på innspill om mulige utviklingstrender fra relevante fagmiljøer. Innføring av PET har skjedd gradvis. Det er flere forhold som tilsier at det har vært en fornuftig tilnærming: fordi teknologien er i stadig utvikling, fordi det har tatt lang tid å dokumentere den kliniske nytten og fordi investerings- og driftskostnadene er svært høye.

\section{Nyttig i pasientbehandlingen?}

Hvorvidt man i Norge burde etablere et PET-senter, kom første gang opp i 2000 og resulterte i den første norske metodevurderingen (Health Technology Assessment) av teknologien. Siden den gang har spørsmålet vært reist flere ganger. Det har resultert i ytterligere fem metodevurderinger (2-6), som har vært benyttet som grunnlag for nasjonale beslutningsprosesser.

Beslutningen om å etablere det første PET-senteret her i landet ble tatt i 2004, begrunnet $\mathrm{i}$ behovet for å bruke teknologien til forskningsformål. På dette tidspunkt var det vist at PET-undersøkelse hadde diagnostiske fortrinn fremfor annen bildediagnostikk for kun noen få tilstander. Det var ikke godt dokumentert at den diagnostiske informasjonen var nyttig i pasientbehandlingen. I senere diskusjoner har man også avventet dokumentasjon på at PET-undersøkelser har betydning for pasientbehandlingen og utfallet. Per i dag er det bare vist betydning ved to kreftformer, nemlig ikke-småcellet lungekreft og Hodgkins lymfom (6-8).

\section{Scenario 2020}

Kapasitet og tilgjengelighet har også stått sentralt $i$ diskusjoner om innføring av PETundersøkelse i norsk helsetjeneste. Det var også tilfellet da Nasjonalt råd for kvalitet og prioritering i helsetjenesten første gang hadde spørsmålet på dagsordenen i 2008 (8).

\section{«Beslutninger om PET er" tatt både på vuirdering av dokumentasjon fra forskning og på innspill om mulige utviklingstrender fra relevante fagmiljøer»»}

På bakgrunn av en utredning, foretatt i fagmiljøene, etterlyste rådet en mer presis angivelse av behovet for teknologien. På oppdrag fra rådet utviklet Nasjonalt kunnskapssenter for helsetjenesten en modell for å estimere utviklingen i antall PETundersøkelser frem mot 2020. Dette ble gjort i samråd med landets ledende krefteksperter.

Konklusjonen var et fremtidig behov for mellom fire og 14 PET-skannere i 2020 (6). Det laveste anslaget var basert på samme bruk som i dag, det høyeste på PET-undersøkelse i all planlegging av strålebehandling. Kvalitets- og prioriteringsrådet anbefalte derfor en gradvis utbygging av PET-kapasiteten for å dekke det til enhver tid gjeldende behov. Rådet understreket at det er de fag- lige retningslinjene som skal være utgangspunktet for antallet årlige undersøkelser i helseforetakene. Retningslinjene skal kun anbefale PET-undersøkelse der det er dokumentert god nytte og der denne står i et rimelig forhold til kostnadene.

\section{Norge på linje med andre land}

I diskusjonene om PET vises det ofte til Danmark, som har et av de mest utbygde tilbudene i Europa (fig 1). I Kunnskapssenterets undersøkelse varierte antall PETsentre fra 0,3 til 3,9 per million innbyggere (6). Etter etablering av ytterligere ett PETsenter i Norge ved Oslo universitetssykehus har dekningen i Norge økt fra 0,6 til 0,8 sentre per million innbyggere.

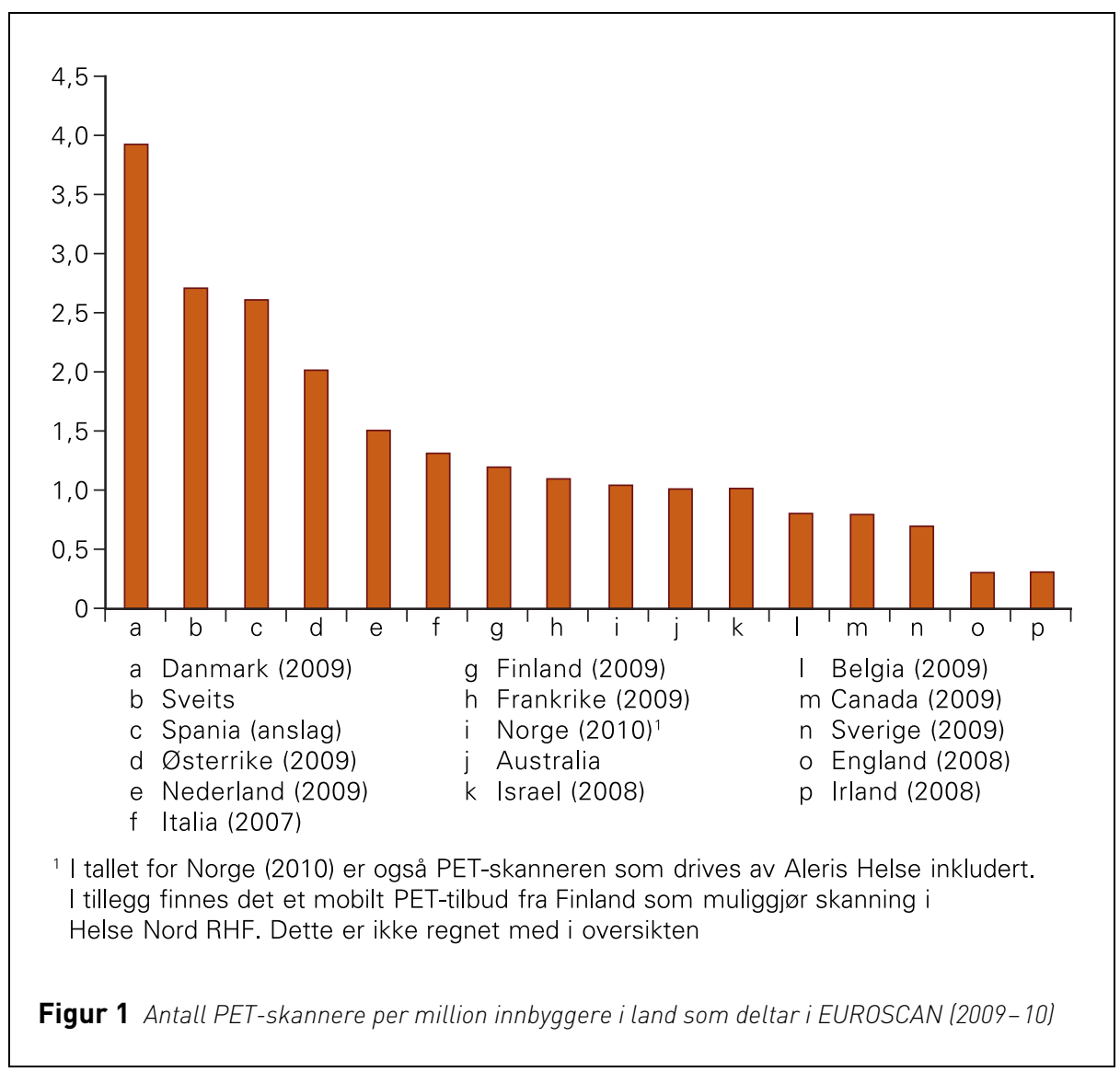


Helsemyndighetene har etter vårt syn fulgt en god og faglig trygg vei de siste ti årene, en vei som også er i tråd med dagens politiske føringer. Innføring av PET-skanning som undersøkelsesmetode bør skje styrt og planlagt, fordi unødig bruk av metoden kan gå på bekostning av billigere og like gode metoder som er tilgjengelige i sykehusene.

Vi vil fremheve tre nøkkelfaktorer som kjennetegner disse prosessene: krav til dokumentasjon av klinisk nytte og positiv kostnad-nytte-effekt, involvering av fagmiljøene i prosessene og et nasjonalt organ som kan gi beslutningstakere råd om innføring av kostbart og avansert utstyr.

\section{Inger Natvig Norderhaug}

inger.norderhaug@kunnskapssenteret.no Nasjonalt kunnskapssenter for helsetjenesten og

Institutt for samfunnsmedisin

Universitetet i Tromsø

\section{Ånen Ringard}

Sekretariatet for Nasjonalt råd for kvalitet og prioritering i helsetjenesten

\section{Berit Mørland}

Nasjonalt kunnskapssenter for helsetjenesten

Sekretariatet for Nasjonalt råd for kvalitet og prioritering i helsetjenesten

\section{Litteratur}

1. Brøyn MB, Fuglehaug W. PET-skanning: fremtidens diagnostikk. Aftenposten 30.8.2010.

2. Smiseth OA, Myhre ES, Aas M et al. Positron emisjonstomografi (PET) - diagnostisk og klinisk nytteverdi. Rapport nr. 8/2000. Oslo: Senter for medisinsk metodevurdering, 2000.

3. Mørland B. Positronemisjonstomografi (PET) diagnostisk og klinisk nytteverdi. Rapport nr. 6/2003. Oslo: Senter for medisinsk metodevurdering, 2003.

4. Graff BA. PET - diagnostisk og klinisk nytteverdi. Oslo: Nasjonalt kunnskapssenter for helsetjenesten, 2006.

5. Johansen K, Mørland B. Prosjektrapport. Bruk av og fremtidig behov for PET i Norge. Oslo: Nasjonalt råd for kvalitet og prioritering, 2008.

6. Graff BA, Jeppesen E, Movik E et al. Estimering av behovet for PET/CT i 2020. Oslo: Nasjonalt kunnskapssenter for helsetjenesten, 2009.

7. Jeppesen E, Juvet L. Klinisk nytte av PET integrert med CT for ikke-småcellet lungekreft. Metodevarsel nr. 3/2010. Oslo: Nasjonalt kunnskapssenter for helsetjenesten, 2010.

8. Nasjonalt råd for kvalitet og prioritering i helsetjenesten. Positronemisjonstomografi. www.kvalitetogprioritering.no/Saker/12488.cms (13.12.2010).

\title{
Epikriser gir læring
}

\author{
Epikrisen er et viktig virkemiddel i kommunikasjonen mellom \\ sykehusene og fastlegene og bidrar til kontinuitet i behandlingen. \\ Men hvem skal og hvem kan epikrisen sendes til?
}

Helse- og omsorgsdepartementet kom 29.6. 2010 med presiseringer i journalforskriften $(1,2)$. Som hovedregel skal det nå sendes epikrise til henvisende helsepersonell i tillegg til pasientens fastlege.

\section{Krav om oppfølgingsansvar?}

I pasientjournalforskriftens $\S 9$ står det at epikrise skal «sendes det helsepersonell som trenger opplysningene for å kunne gi pasienten forsvarlig oppfølgning» (1). Tredje ledd i samme paragraf åpner for at epikrisen også kan sendes til innleggende/ henvisende helsepersonell. Denne bestemmelsen er inntil nå blitt tolket svært restriktivt, slik at man for å kunne sikkerhet for pasientene. Sentralstyret i Legeforeningen vedtok 28.4. 2008, etter forslag fra utvalget, en handlingsplan for pasientsikkerhet (4). Utvalget arbeider kontinuerlig med å foreslå tiltak som skal oppfylle handlingsplanen. Ett av disse har vært å stimulere helseforetak til å sende epikriser til legevaktleger og andre innleggende leger, slik at henvisende lege i læringsøyemed kan få kjennskap til endelig diagnose og behandling.

Departementets presiseringer om utsendelse av epikrise er en kjærkommen tolking av regelverket og understøtter utvalgets syn. Det som gjenstår, er at de regionale helseforetakene, som er adressater

\section{«Som hovedregel skal det nå sendes epikrise til henvisende helsepersonell i tillegg til pasientens fastlege»}

motta epikrise må ha et oppfølgingsansvar for pasienten, med mindre vedkommende aktivt gir sitt samtykke. De fleste legevaktleger har ikke noe slikt oppfølgingsansvar og har derfor heller ikke hatt muligheten til å lære gjennom å få tilbakemelding på diagnostisering og eventuell påbegynt behandling.

Problemstillingen ble reist gjennom en henvendelse fra Helse Sør-Øst til Helseog omsorgsdepartementet 15.10. 2009 (3), etter at helsetilsynet i Telemark for noen år tilbake tok et initiativ for at legevaktlegene skulle kunne dra nytte av epikrisen til å lære av og eventuelt korrigere sin atferd. Helse- og omsorgsdepartementet har i brev av 29.6. 2010 (2) til Helse Sør-Øst, med gjenpart til øvrige regionale helseforetak, kommet med presiseringer om at epikrisen som hovedregel skal sendes til henvisende helsepersonell i tillegg til pasientens fastlege. Dette vil måtte føre til endret praksis for de fleste helseforetak.

\section{Læring}

Legeforeningens utvalg for kvalitet og pasientsikkerhet er opptatt av hvordan epikrisen kan bidra til læring og endring av klinisk praksis og dermed til bedre for presiseringen, tar de nødvendige initiativer for å endre praksis i den kliniske hverdag.

\section{Gunnar Andersen \\ gunnara@online.no \\ Porsgrunn legesenter \\ Augestadveien 7 \\ 3915 Porsgrunn}

Oppgitte interessekonflikter: Forfatteren er medlem av Legeforeningens utvalg for kvalitet og pasientsikkerhet.

\section{Litteratur}

1 FOR 2000-12-21 nr 1385: Forskrift om pasientjournal. www.lovdata.no/cgi-wift/ldles?doc=/sf/ sf/sf-20001221-1385.html (15.10.2010).

2. Brev av 29.6. 2010 til Helse Sør-Øst RHF. Vedrørende regelverket om utsending av epikriser. Oslo: Helse- og omsorgsdepartementet, 2010.

3. Brev av 15.10. 2009 til Helse- og omsorgsdepartementet. Anmodning om vurdering av regelverket om utsending av epikrise. Hamar: Helse SørØst RHF, 2009.

4. Legeforeningens handlingsplan for pasientsikkerhet. www.legeforeningen.no/id/146188.0 (18.12.2010).

Mottatt 1.10. 2010, første revisjon innsendt 14.11. 2010, godkjent 23.12. 2010. Medisinsk redaktør Mette Sagsveen. 